\title{
To Deter and Deny: Australia and the Interdiction of Asylum Seekers
}

\author{
Jessica Howard
}

\begin{abstract}
The paper provides an overview of the development and implementation of Australia's comprehensive 'border protection' policy, including the Pacific Solution and Operation Relex - the interdiction of asylum seekers. The intention of the paper is to demonstrate the lengths to which a developed state will go in addressing the interrelated problems of secondary movement, people smuggling and mixed flows. It also highlights the 'export value' of the policy and its wider implications.
\end{abstract}

\section{Résumé}

Cet article propose un survol du développement et de la mise en vigueur de la politique intégrée australienne de "défense des frontières ", y compris la Solution du Pacifique et Relex - l'interdiction des demandeurs d'asile. L'article vise à montrer jusqu'où un état avancé est disposé à aller pour confronter les problèmes connexes de mouvement secondaire, de la traite des gens et des flots mixtes. Il met aussi en exergue la valeur "à l'export » de cette politique et ses applications possibles dans d'autres domaines.

\section{Introduction}
$\Lambda$ ustralia is not normally considered to be a country facing a refugee or asylum seeker "problem." Cer- - 1 tainly, by European or African standards, the number of asylum seekers and refugees arriving on Austra- lian shores in any year is minuscule. However, the high profile rescue by the MV Tampa of over 400 people attempt- ing to reach Australia and claim asylum catapulted the Australian treatment of asylum seekers onto the world stage. The MV Tampa saga provided the impetus for the introduc-

tion by the Australian government of a new policy approach to "unauthorized arrivals." The catchphrase for this new policy was the "Pacific Solution" and entailed the use of neighbouring Pacific states as refugee holding pens and a concerted naval interdiction campaign. Unlike the MV Tampa incident, which has been the subject of considerable academic discussion, ${ }^{1}$ Australia's naval interdiction campaign (known as "Operation Relex") has received scant consideration, despite having potentially significant ramifications for the treatment of asylum seekers by other Western states.

The purpose of this paper is to provide an overview of the development and implementation of Australia's "border protection" policy, including the Pacific Solution and Operation Relex. Whilst the policy raises significant questions about Australia's compliance with international obligations owed to asylum seekers and refugees and the legality of certain activities at sea, it is not the purpose of this paper to canvass these in any detail. Rather, the intention is to demonstrate the lengths to which a developed state will go in addressing the interrelated problems of secondary movement, people smuggling, and mixed flows. In the case of Australia, ensuring the sanctity of its borders in a climate of heightened security fears took primacy over its obligation to abide by the spirit, if not the letter, of the Refugee Convention. ${ }^{2}$ The "export value" of Australia's new policy means that the 'Pacific Solution' may have an impact on the nature of asylum regimes around the world. ${ }^{3}$

\section{Australian Government Responses to Unauthorized Arrivals}

As a relatively young country, Australia has relied heavily on immigration to achieve population and economic growth. More than six million people have come to Australia as migrants since $1945 .{ }^{4}$ Australia has a well-developed and 
strictly controlled immigration system, which includes a universal visa system for all non-citizens coming to Australia. The Department of Immigration and Multicultural and Indigenous Affairs (DIMIA) $)^{5}$ is responsible for the administration of Australia's official migration program, including the humanitarian and refugee intake.

Australia is a signatory to both the Refugee Convention and the 1967 Protocol, ${ }^{6}$ which together shall be referred to as the Refugee Convention. Historically, Australia has resettled large numbers of refugees and other persons of humanitarian concern from overseas camps; it remains one of only a handful of active "resettlement" countries. ${ }^{7}$ Unlike many other countries, however, Australia has not faced mass influxes of refugees or large numbers of asylum seekers arriving in its territory. This has enabled Australia to tightly control all aspects of its immigration program, including refugee numbers. The arrival of increasing numbers of asylum seekers on Australia's shores presented a real challenge to this "culture of control."

The Australian government's policy and legislation on unauthorized arrivals has historically displayed an acute bias towards boat arrivals, rather than those arriving "illegally" by air. This is so, in spite of the fact that, until the late 1990s, unauthorized air arrivals outstripped unauthorized boat arrivals to Australia. The fear of immigrants from Australia's populous northern neighbours flooding through porous and unprotected coastal borders looms large in Australian mythology.

The first significant Australian government action to combat increasing unauthorized arrivals was in response to the arrival of Indochinese refugees in the early 1990s. The Australian government amended the Migration Act 1958 (Cth) to provide for the mandatory detention of the Indochinese "boat people" in 1992. ${ }^{9}$ Boat arrivals throughout the 1990s remained very low; however, there was a sharp increase in 1998-99. One explanation for this change was the increase in people smuggling activities in the region, largely moving Afghan, Iranian, and Iraqi refugees and asylum seekers. Despite being cast as undeserving "queue jumpers," the vast majority (90 per cent of arrivals from 1998 to 2001$)^{10}$ of unauthorized boat arrivals demonstrate that they are refugees in need of protection and have been successful in their claim for asylum in Australia.

Since 1999, increasingly restrictive practices in relation to unauthorized arrivals in general, and people smuggling in particular, have been introduced by the Australian government. These practices culminated in the implementation of a comprehensive border protection (read "refugee control") strategy in September 2001 - the so-called "Pacific Solution." As of 6 November 2003, there had been only three unauthorized boat arrivals in Australia (two from Vietnam with fewer than one hundred people in total and one carrying fourteen Turkish Kurds), since 16 December 2001.

\section{A. The Development of the Border Protection Strategy}

In 1999, two vessels carrying unauthorized arrivals landed, undetected, on the east coast of mainland Australia. Boat arrivals had previously only landed in Australia's remote northern reaches and offshore territories. Australia has a number of island territories to its north, including Christmas Island, Ashmore Reef, and Cocos Island, all of which are proximate to Indonesia, a major transit country for people smuggling to Australia. In response to these arrivals, the Australian government created the Coastal Surveillance Task Force (CSTF) to make recommendations on the strengthening of Australia's coastal surveillance procedures and systems. This was the first step towards the creation and implementation of the Pacific Solution.

The CSTF recommended a four-year, A\$124 million program to "strengthen Australia's capacity to detect and deter illegal arrivals," 11 which was accepted by the government. One of the specific recommendations was the need for a coordinated administrative approach to unauthorized arrivals. This led to the creation of a second task force in late 1999 - the Unauthorized Arrivals in Australia Task Force (UATF) - which was to report on:

issues of international cooperation to combat irregular migration and people smuggling; measures to bolster the international protection framework; and steps to improve coordination and efficiency among Australian Government agencies. $^{12}$

The UATF report resulted in the adoption of a "comprehensive and integrated unauthorized arrivals strategy."13 There are three key elements to this strategy: prevention of irregular migration; disruption of people smugglers and their clients en route; and the development of "appropriate reception arrangements." Much of the unauthorized arrivals strategy developed by the UATF remains in place today; however, it has been modified and extended over time, particularly in late 2001 .

The prevention of irregular migration involved:

- the use of targeted aid funding to help eliminate "push factors" in key source countries (Afghanistan and Pakistan in particular);

- the implementation of domestic and international information campaigns; 
- increased technical co-operation, capacity building, and information exchange with key source countries (focusing on the Middle East), and

- efforts to increase international co-operation on irregular migration and people smuggling.

Strategies aimed at disrupting people smugglers included the posting of additional compliance and airline liaison officers in overseas locations; technical co-operation and capacity building with key transit countries in the region; ${ }^{14}$ improved intelligence gathering and exchange; and increased efforts to obtain regional co-operation on the interception of irregular migrants. The most comprehensive regional co-operation model implemented to date is with Indonesia - the key transit country for unauthorized boat arrivals to Australia.

The final aspect of the strategy was coordinated reception arrangements in Australia. This comprised a continued commitment to the use of mandatory detention (including the establishment of the remote detention centres in the desert regions of Australia), improved processing times, negotiations with countries of origin and first asylum for the return of failed asylum seekers, and a raft of legislative amendments "to reduce the incentives of using Australian refugee law to achieve a migration outcome."15

\section{Refugee Controls and Border Protection}

The unauthorized arrival strategy saw no immediate reduction in the number of boat arrivals. It appears to have been effective in easing the general upwards trend in unauthorized air arrivals, which comprised about a third of all unauthorized arrivals in the 1999-2000 financial year. However, the number of boat arrivals in 1999-2000 and 2000-01 remained relatively steady, at around 4,000 annually. Despite the unauthorized arrivals strategy having been in place for two years, there was a strong feeling amongst senior government representatives that people smugglers saw Australia as a "soft touch."

\section{A. The MV Tampa and the Pacific Solution}

The sense that the unauthorized arrivals strategy was not achieving its aim was strengthened by the arrival of 1,212 people in six boats in the first three weeks of August 2001. ${ }^{16}$ The boats arrived at the Australian offshore territories of Ashmore Reef and Christmas Island. In accordance with the established policy (and authorized by the Migration Act 1958 (Cth)) all of these boats were detained and the people on board were taken to detention centres on mainland Australia for immigration processing. ${ }^{17}$ However, this policy was to soon change.
On 26 August 2001, the Norwegian flagged freighter MV Tampa rescued in excess of 400 people from a twenty-metre wooden fishing vessel that was sinking about 140 kilometres north of Christmas Island. The rescue had occurred at the request of Australian authorities, who believed there were approximately eighty people on board the sinking vessel. The "rescuees," as they became known, were mostly from Afghanistan, having departed Indonesia by boat to seek asylum in Australia. ${ }^{18}$

The captain of the MV Tampa, Captain Arne Rinnan, intended to return the rescuees to Indonesia; however, several of the asylum seekers made threats to harm themselves if they were not taken to Australia. Captain Rinnan decided to change course for Christmas Island. Upon reaching Christmas Island, the MV Tampa was denied entry to Australian territorial waters. ${ }^{19}$ A standoff ensued and the MV Tampa sat just outside Australian territorial waters for three days.

During that time, the rescuees were housed on the deck of the ship, with only empty cargo containers for shelter. Many were suffering dehydration, some quite severely. Captain Rinnan informed the Australian government that if the medical situation on board was not addressed immediately, people would die shortly. The Australian government did not respond to requests for medical assistance, food, and the removal of the sickest people. ${ }^{20}$

At about 11.30 a.m. on Thursday, 29 August, Captain Rinnan decided to enter Australian waters and stopped about four nautical miles off the coast of Christmas Island. He determined not to leave until the humanitarian situation was addressed and the "rescuees" allowed to disembark. The Australian government response was swift and decisive. In around one hour, it ordered forty-five armed SAS (Special Air Services) troops to board the MV Tampa and closed the port at Christmas Island to incoming and outgoing traffic.

Soon after the boarding by SAS personnel, Prime Minister John Howard announced that not one of the "rescuees" on board the MV Tampa would set foot on Australian soil. ${ }^{21}$ The government decision was the subject of legal proceedings in the Federal Court of Australia, which initially determined that the "rescuees" were being unlawfully detained by the government. ${ }^{22}$ This decision was overturned, by majority, on appeal. ${ }^{23}$

While the court proceedings were being heard, the government obtained the agreement of the impoverished $\mathrm{Pa}-$ cific island nation of Nauru to house the MV Tampa "rescuees," in exchange for significant aid contributions and debt write-offs. ${ }^{24}$ In addition, New Zealand agreed to 
accept 150 rescuees - primarily women, children, and family groups - for processing. ${ }^{25}$

The "rescuees" were removed from the MV Tampa and transported to Nauru on board HMAS Manoora, an Australian warship. Upon arrival in Nauru, they were detained in compounds managed by the International Organization for Migration (IOM). ${ }^{26}$ The UNHCR accepted a request from Nauru for assistance in the processing of asylum claims of those rescued from the MV Tampa. ${ }^{27}$ All costs associated with the housing, detention, and processing of the rescuees on Nauru, including those incurred by the UNHCR, were to be met by the Australian government. ${ }^{28}$

The government's response to the MV Tampa situation was coordinated through the creation of a high-level, interdepartmental committee to be known as the People Smuggling Taskforce (PSTF) on 27 September 2001. The PSTF was created partly in response to the MV Tampa, and partly due to intelligence suggesting there were a range of boats planning to come to Australia from Indonesia in the near future. These two issues required there be a "concerted focus" on what was happening and the possible government responses. ${ }^{29}$

Despite being an ad hoc response to the MV Tampa incident, the establishment of the PSTF signalled a change to a "whole of government" approach to the question of unauthorized arrivals and people smuggling. Prior to this time, intelligence exchange and liaison about potential boat arrivals had occurred at the working level between DIMIA, the Australian Federal Police (AFP) and Coastwatch (a branch of the Australian Customs Service). It was also to signal the start of a new government policy on boat arrivals and people smuggling.

The arrival of further boatloads of asylum seekers saw the Australian government extend its so-called "Pacific Solution" to a second compound on Nauru and a third compound on Manus Island in Papua New Guinea. ${ }^{30}$ These too were managed by IOM. However, the UNHCR refused to process any of these further arrivals. Instead, the Australian government established a new offshore processing regime using DIMIA officials. The Nauru facilities were used primarily for Afghan asylum seekers and Manus Island for Iraqis. The Australian government once again met all costs associated with these "offshore processing centres." On the question of costs, the Select Committee concluded that:

Although substantial information is available on the costs associated with the operation of the offshore processing centres in Nauru and Papua New Guinea, the Committee has not been able to collate an accurate picture of the full cost of the Pacific Solution. The substantive difficulty arises from the inability to fully identify the cost of the activities of the Australian Defence Force in support of the arrangements. ${ }^{31}$

The Committee does quantify the non-Defence related costs of the Pacific Solution, which total in excess of A $\$ 250$ million. ${ }^{32}$ These expenses relate to the reception and processing of 1,515 asylum seekers in Nauru and Papua New Guinea. According to DIMIA, the estimated average cost for each unauthorized arrival that is processed in Australia is $\$ 29,000 .^{33}$ This means that if all the asylum seekers taken to Nauru and Papua New Guinea had been processed in Australia, the average total cost would have been around A \$44 million.

The Select Committee noted that:

[I]t is apparent that the cost of the Pacific Solution processing arrangements on Nauru and Manus to date, including additional aid funding, have been significantly more expensive than onshore processing of the same number of people. This is true even without a full accounting of the cost of the supporting services provided by the Defence Force. ${ }^{34}$

\section{B. To Deter and Deny - Operation Relex}

The MV Tampa incident marked the introduction of a new comprehensive border protection regime, of which the " $\mathrm{Pa}-$ cific Solution" formed a part. Central to this regime was "Operation Relex," an Australian Defence Force (ADF) mission with the aim of deterring and denying boats suspected of carrying asylum seekers from entering Australian territorial waters.

On 28 August 2001, ${ }^{35}$ the Chief of Defence Forces issued a warning order initiating Operation Relex. It specified that the ADF mission was to "deter unauthorized boat arrivals from entering Australian territorial waters off the north west coast and offshore territories" by providing:

a maritime patrol and response option to detect, intercept and warn vessels carrying unauthorized arrivals for the purpose of deterring suspected illegal entry vessels from entering Australian territorial waters. ${ }^{36}$

Operation Relex formed part of the "whole of government" approach to the issue of unauthorized arrivals and people smuggling. As such, ADF operations were only a part of the overall strategy, which comprised a continuum of operations:

- intelligence gathering and analysis in preparation for possible boat departures from Indonesia, usually by non-ADF personnel; 
- surveillance of the areas in which approaches to Australia would be likely;

- naval interception of any suspected illegal entry vessels (SIEVs) once close to Australia's contiguous zone;

- the provision of warnings to the crew not to enter Australian waters;

- if the SIEV proceeded into the Australian contiguous zone, the insertion of a boarding party, with the aim of removing the boat to the high seas;

- the eventual detention of any SIEV that persisted in its attempts to enter Australian territorial waters; and

- the transfer of detained SIEVs to a designated holding area, pending a government determination on transfer and/or transportation.

This policy was later amended to include the forcible return of vessels to Indonesia.

\section{Surveillance and interception of SIEVs}

Prior to the MV Tampa incident, surveillance of Australia's northern approaches was the responsibility of Coastwatch, a branch of the Australian Customs Service. However, under Operation Relex, the lead responsibility for surveillance within the area of operations was held by Defence.

The surveillance conducted by Defence consisted of air surveillance from the Australian mainland to within thirty miles of the Indonesian archipelago, coupled with the positioning of naval vessels closer to Australian territory. ${ }^{37}$

We [Defence] had a standard operating procedure, which we developed for this operation. That involved ships intercepting an illegal vessel, either primarily by the ship itself or after having been detected by the aircraft that were in surveillance. ${ }^{38}$

Coastwatch was responsible for the "residual national surveillance program ... and the provision of support for Defence in the Operation Relex areas in the Timor and Arafura Sea approaches." 39

SIEVs would be intercepted on the high seas, generally in the vicinity of Christmas Island or Ashmore Reef. Defence personnel only had authority to board the vessels once they entered Australia's contiguous zone, which commences twenty-four nautical miles from land. Interceptions could occur much further out than twenty-four nautical miles; however, naval vessels would then have to shadow the SIEV until it entered the contiguous zone before any action could be taken. For this reason, and in order to militate against the risk of another SIEV slipping through, naval vessels were not positioned too far "up threat." 40

Naval frigates were not directly involved in the interception and boarding of SIEVs. Rather, rigid hull inflatable boats (RHIBs) were sent forward to meet the SIEV with the frigate remaining positioned downstream, just over the horizon. This approach was designed to minimize the risk of a safety-of-life-at-sea situation being generated. There was a fear that the sight of a large vessel capable of rescuing all persons on board the SIEV would be the catalyst for attempts to sabotage the SIEV, thereby creating a rescue situation. ${ }^{41}$

\section{Warning issued to crew}

Upon interception of an SIEV, the personnel on board the RHIB would issue a warning to the master of the vessel, if one was identified, or otherwise to the crew. ${ }^{42}$ The warning advised that the master and/or crew would be breaching Australian law if they proceeded into Australian territory and that they would be subject to severe penalties under that law. ${ }^{43}$ The text of the warning was provided in both English and Bahasa (Indonesian), given that the crews were invariably Indonesian nationals. The warning advised that people smuggling was a criminal offence in Australia subject to mandatory jail terms and large fines. It recommended the crew turn the boat around and return to Indonesia.

Whether or not the warning was comprehended by the crew or the asylum seekers on board the SIEVs is unknown; however, it was assumed by Australian officials that the warning was read and understood. ${ }^{44}$ It appears that in every instance the warnings were ineffective in stopping the boats from continuing towards Australian waters. ${ }^{45}$ No specific warning was issued to the asylum seekers on board the vessels about their likely treatment upon arrival in Australia.

\section{Boarding of SIEVs}

The naval vessel would then shadow the SIEV as it proceeded towards the Australian contiguous zone. Warnings would continue to be given to the vessel, in preparation for boarding. The boarding of the SIEV could be either compliant or non-compliant. Where the boarding was compliant the SIEV was often broken down and in need of assistance, or else responded to a request to heave to, allowing the insertion of the boarding party. In the case of a non-compliant boarding, requests to heave to were usually ignored, requiring more forceful measures to be used to embark the boarding party. In at least one instance, machine gun warning shots were fired into the water ahead of the SIEV and a searchlight was used to illuminate both the weapon firer and the area in the water ahead of the vessel where the rounds were to land.$^{46}$ Other tactics included manoeuvring the naval vessel close to the SIEV to create a distraction, allowing "an assault type non-compliant boarding, using the RHIB, to be effected whilst the vessel was still under way." ${ }^{\prime 7}$ 
Once embarked, the boarding party commandeered the ship and prevented any further damage being occasioned to the vessel. ${ }^{48}$ Initially, the boarding party comprised naval personnel only. As Operation Relex progressed, it was decided that an armed presence in the boarding party was required in order to ensure control of the vessel..$^{49}$ This armed presence was known as the Transit Security Element (TSE) and included members of the Australian Army.

Members of the boarding party were armed with a holstered pistol and a baton. ${ }^{50}$ The Rules of Engagement (ROE) for Operation Relex stipulated the level of force which the boarding parties were authorized to use. ${ }^{51}$ Whilst the weapons carried by the boarding party were visible, personnel were not authorized to use lethal force except in self-defence. The members of the boarding party were advised that the use of force should always be consistent with the situation they found themselves in and should be kept to a minimum..$^{52}$

A range of options for controlling people on board the vessels was employed. The naval personnel were trained in the used of batons. The army personnel also carried and were trained to use capsicum spray and electricians' cable ties to temporarily restrain people. Both of these methods of controlling the situation were used in the course of Operation Relex. ${ }^{53}$

The boarding party would include at least one engineer who would inspect the engine and other members of the boarding party would assess the hull and other parts of the vessel. ${ }^{54}$ The boarding party would then assess the mechanical engineering, navigational equipment, and general seaworthiness of the SIEV, and any minor repairs necessary to ensure continued seaworthiness would also be made. ${ }^{55}$ The boarding party would also provide basic medical assistance and estimate the number of passengers on board.

Once a boarding had been effected, the established policy was to

reinforce the warning and turn the vessel around and either steam it out of our contiguous zone ourselves under its own power or - as had happened on a number of occasions - if the engine had been sabotaged in our process of boarding, we would then tow the vessel outside our contiguous zone into international waters. ${ }^{56}$

The boarding party would remain on the SIEV until it reached the outer limit of the Australian contiguous zone, at which point it would return to the naval vessel. The naval vessel would closely escort the SIEV, if it was not under tow, until the Indonesian twenty-four nautical mile limit, at which point it would instruct the vessel to continue back towards Indonesia. The naval vessel would then withdraw over the horizon, outside the nominal visual range and would monitor the SIEV using an electro-optical tracking system. The SIEVs "invariably just turned around and came back again." ${ }^{57}$

According to Rear Admiral Smith, the "initial policy was to do that up to three times and, after having done it the third time, to seek further advice from government" ${ }^{38}$ about what to do with the vessel. The decision about what was to happen with the SIEV was one made by government, again through the PSTF process.

\section{Containment of SIEVs and transportation}

Initially, any SIEV which persisted in its attempts to enter Australia, or which foundered whilst attempting to enter Australia, was contained by the ADF until a decision was made as to where the boat and/or passengers were to be taken. The circumstances of containment varied for each SIEV and are outlined in Appendix 1. The common element, however, was the requirement that no persons from any SIEV were to land on Australian territory. Many persons were contained on vessels within Australian territorial waters, but none were allowed to land, even when land was very close by. ${ }^{59}$

As discussed above, the Pacific Solution saw the establishment of two processing camps on Nauru - one for the MV Tampa asylum seekers, the other for subsequent arrivals - and one camp on Manus Island. The people on board each SIEV that was not returned to Indonesia were taken to either Nauru or Manus Island for processing. There is one exception to this, and that is SIEV 8, which had thirty-one people on board, and had departed from Vietnam, not Indonesia. After being detained at Christmas Island for a short period of time, these people were taken to the Australian territory of Cocos Island for processing. The reason for the different processing locations is something that can only be speculated about, but is probably due to the fact these asylum seekers were not "secondary" movers and had not engaged the services of a people smuggler to get to Australia.

DIMIA developed written scripts to inform the asylum seekers about where they were being transported to, what to expect upon arrival, and their future options. The notable exception is the script used for SIEV 4 - the first group to be sent to Manus Island - in which the destination does not seem to have been revealed. Unlike the people taken to Nauru, this group was not transported by navy vessel; rather, they were flown to Papua New Guinea. 


\section{Forcible return to Indonesia}

In early October, a request was conveyed to the PSTF to prepare a report on the feasibility of returning SIEVs to Indonesia once intercepted. The PSTF discussed the matter on 11 October 2001 and provided the draft report to the Secretaries Committee on National Security (SCONS) on 12 October 2001. ${ }^{60}$

The PSTF report advised that, subject to a number of limitations particularly relating to the seaworthiness of the vessel, it was possible to return SIEVs to Indonesia. The report acknowledged that not every vessel could be returned. The overriding considerations would be safety-oflife-at-sea issues and Australia's international obligations to assist those in distress. Whether or not a vessel was seaworthy enough to make it back to Indonesia safely would remain a matter of judgment for the relevant naval commander. ${ }^{61}$ Interestingly, the caveats on return did not include any consideration of people's claims to be refugees.

The SCONS drafted a minute to be transmitted to Prime Minister Howard, suggesting that the policy of tow-backs to Indonesia be instituted, and the Prime Minister agreed to this policy change on or around 12 October 2001. The first boat to be subject to the policy was SIEV 5, which was intercepted on 12 October and held off Ashmore Reef until 17 October, at which time it was escorted back to Indonesia.

The "tow-back" policy essentially constituted the interception of SIEVs and forcible return of the vessels under Navy escort to within close proximity of Indonesian territorial waters. Vice Admiral Shackleton, Chief of Navy, stated that when the Navy takes a ship back to Indonesia, "we essentially navigate on its behalf, and we leave it within sight of the Indonesian coast." 62 Australian vessels involved in tow-backs apparently did not at any stage enter Indonesian territorial waters; rather, they escorted the SIEVs to the edge of the Indonesian contiguous zone, from which point the SIEVs continued under their own steam back into Indonesian territorial waters. ${ }^{63}$

The Indonesian government was apparently notified of the return of each of the four SIEVs subject to the "tow-back policy." ${ }^{64}$ The official Australian position is that the place to which each of the boats actually returned is unknown. However, it is known that one (SIEV 12) ran aground on Roti Island, just off the coast of West Timor. The Navy returned the three other SIEVs to the Indonesian waters in the West Timor area - one near Kupang (SIEV 5) and the other two near the town of Pepela, Roti (SEIV 7 and 11). ${ }^{65}$ It is estimated that in total there were over 500 people on board these four SIEVs.

Given the level of intelligence gathering by Australian authorities in Indonesia, it is implausible that Australia has no knowledge of where these boats returned to or what happened to the people on board. It is also a gross abdication of the international obligation owed to asylum seekers to ensure that they are not subjected to refoulement by Indonesia. ${ }^{66}$ According to Mr Killesteyn, Deputy Secretary of DIMIA, Australia's involvement ceased once the Indonesian government was informed that the boats were returned to Indonesian territorial waters and " $[\mathrm{w}]$ hat then happened in terms of reception arrangements is really a matter for the Indonesian government." ${ }^{67}$ As is apparent from the discussion below of the Regional Cooperation Model in place between Australia and Indonesia, it is in fact inconsistent with the structure and purpose of those arrangements that Australia had no further information on, or involvement in, the interception, detention, and processing of those returned to Indonesia.

\section{Regional Cooperation Model with Indonesia}

The anti-people smuggling arrangements in place between Australia and Indonesia are the longest standing and most developed in the region. ${ }^{68}$ In early 2000, Australia proposed a Regional Cooperation Model (RCM) with Indonesia, including the co-operation of the International Organisation for Migration (IOM) and UNHCR. According to DIMIA, the RCM provides for the interception and detention of asylum seekers, assessment of protection claims, and arrangements for removal of failed asylum seekers or resettlement of recognized refugees. Under the arrangements in place, Australia and Indonesia have agreed

to cooperate to disrupt [the flow of unauthorized arrivals] by taking concerted action to intercept people who are breaching Indonesia's immigration laws and to take an active approach to putting an end to the operations of people smugglers who are based in Indonesia. ${ }^{69}$

\section{A. Implementation of the Regional Cooperation Model}

In order to ensure that its non-refoulement obligations under the Refugee Convention were not breached, Australia needed to ensure that the RCM provided asylum seekers with an opportunity to have their claims for protection assessed. UNHCR did not agree to take a leading role in the implementation of the model, and initially it refused to endorse, or even participate in, the RCM. ${ }^{70}$ The function of "lead agency" was taken on by IOM.

Despite UNHCR's initial reluctance to be involved, it has a statutory responsibility to interview anyone who expresses a wish to request asylum. ${ }^{71}$ Whilst UNHCR did not agree to assist the Australian government by actively seeking out asylum seekers in Indonesia, it had no choice but to 
agree to assess any claims lodged with its (small) Jakarta office. ${ }^{72}$ IOM undertook to inform intercepted asylum seekers of this option.

Under the RCM, the interception of illegal third-country nationals in Indonesia is the responsibility of local Indonesian authorities, primarily the Indonesian National Police service (INP). Whilst Australia has federal police officers on the ground in Indonesia, they have no law enforcement jurisdiction outside Australia. Thus, the stated Australian policy of disruption and interception required co-operation from local police in order to be effective. This co-operation is ensured through a protocol concluded in 2000 and renegotiated in 2002 between the two police services, and is discussed in detail below.

The interception of unauthorized migrants by the INP predominantly results from Australian intelligence about the locations and movements of people or from information provided by human sources, such as hotel staff or other informants, to the Indonesian authorities. Any person who is intercepted by the INP and found to be undocumented, in possession of fake documentation, or without a valid Indonesian visa is usually arrested. Once arrested, the persons are transferred to the custody of Indonesian immigration authorities. IOM, the Australian embassy in Jakarta, and UNHCR are subsequently advised of the arrests. It seems that Australia has a tacit agreement with Indonesian authorities that they will not réfoule people who may be asylum seekers, despite the fact that Indonesia is not a party to the Refugee Convention. Australia has not declared Indonesia to be a "safe third country" under the Migration Act 1958, and has no formal readmission agreement with Indonesia. This is particularly concerning as it leaves returned and intercepted asylum seekers at risk of "chain refoulement."

Those persons who are intercepted and arrested are then detained in a variety of places in Indonesia, ranging from immigration detention facilities to hotels. IOM staff members attend the locations where the unauthorized migrants are being held and arrange for longer-term accommodation. The Australian government meets the costs of IOM in providing accommodation, food, and medical assistance to those detained. IOM also arranges longer-term accommodation if it is required, (for example, while refugee status determination is conducted by UNHCR).

Regardless of where unauthorized migrants are located, they remain the responsibility of IOM and are strictly in "detention" until they leave Indonesia. ${ }^{73}$ In reality, the detention arrangements are not particularly secure, leading to a number of persons leaving the accommodation. It is not known whether those persons have remained in or left
Indonesia, and, if they have left, whether they travelled to Australia or to some other location.

IOM also has the responsibility of advising those arrested of their options for the future. These include voluntary return to their country of origin, return to another country which recognizes their right of entry, or contacting UNHCR to make an application for refugee status. According to the Deputy Secretary of DIMIA, the co-operation with UNHCR

was specifically designed to give these people, who were enjoying protection in Indonesia at the time, an opportunity to have their claims assessed and for resettlement processes to start. ${ }^{74}$

One problem with this approach is that it has lead to a burden shift from Australia's onshore processing system, which is very well-resourced, to the UNHCR's Jakarta office, which is chronically under-resourced. Traditionally a small office, it has not been equipped to process the increasing number of claims lodged in Indonesia for which it is responsible. This has led to problems of delay in processing claims. The problems of delay have been compounded by an unwillingness on the part of states parties to the Refugee Convention to then resettle designated refugees located in Indonesia.

People found to have protection needs remain the responsibility of UNHCR, which then seeks a durable solution for each refugee, usually in the form of resettlement in a third country. As Indonesia is not a signatory to the Refugee Convention, no durable solutions are available for refugees in Indonesia. Those indicating a desire to leave Indonesia are assisted by IOM to do so and Australia meets the costs incurred in organizing the voluntary removal of unauthorized migrants. Approximately 10 per cent of persons intercepted decide to voluntarily return to their country of origin. ${ }^{75}$ If a person is found by UNHCR as not having protection needs, IOM arranges to remove from Indonesia those wanting to return home, with the costs again met by the Australian government.

\section{B. Co-operation between Australian Federal Police and Indonesian National Police}

Despite its formal title, the RCM is not a high-level arrangement between governments. Rather, it is a primarily a cooperative arrangement between the law enforcement agencies of Australia and Indonesia - the Australian Federal Police (AFP) and the Indonesian National Police (INP).

The AFP is the law enforcement agency for the federal government in Australia, and enforces Commonwealth (as 
opposed to State) laws, including the Migration Act 1958 (Cth). In the area of people smuggling, the AFP

engages in targeting facilitators of people-smuggling ventures. These are the people who arrange for the marketing of opportunities for potential passengers, organise their travel to embarkation points, coordinate and provide vessels and employ crews. ${ }^{76}$

The AFP is also partly responsible for the investigation and prosecution of the crews of SIEV s for people smuggling offences under the Migration Act 1958 (Cth). ${ }^{77}$

The co-operative regime between the AFP and the INP in relation to people smuggling is given effect through a specific protocol concluded in 2000. On 27 October 1995, the AFP entered into a Memorandum of Understanding (MOU) with the Indonesian National Police to co-operate in the investigation of transnational crime. The MOU was renewed on 5 August 1997. On 15 September 2000, the AFP entered into a specific protocol under the MOU "to target people smuggling syndicates operating out of Indonesia."78 Two weeks later, on 27 September 2000, a ministerial direction was issued to the AFP, directing the AFP to "give special emphasis to countering and otherwise investigating organised people smuggling." 79

According to the Commissioner of the AFP, Mr. M. Keelty,

Under the provisions of the Protocol, the AFP did fund INP units to take part in anti-people smuggling operations ... The Protocol laid out the level of accountability that would have to be met by the various INP units ...

The Protocol allowed for the AFP and INP to provide advice regarding target selection, technical and management support of operations, informant management, information facilitation and assistance in financial reporting. ${ }^{80}$

Action was taken under the Protocol almost immediately, including the training of five INP Special Intelligence Units in October, the provision of equipment to those units in November and the allocation of funds to coordinate operations (including the INP Interpol office) and pay the INP informant network. ${ }^{81}$

Under the Protocol, however, the AFP "cannot direct the INP ... [w] e can seek their cooperation.” The INP Special Intelligence Units have been involved in gathering information, making arrests and prosecuting Indonesian-based people smugglers. ${ }^{82}$ The Special Intelligence Units were also central to the Australian policy of disruption in Indonesia.

On or around 12 September 2001, the Indonesian government set aside the Protocol. Apparently, it is unclear why this occurred. The AFP have stated that the only reason they were given was that the Indonesian government desired a more formal, government-to-government agreement, rather than the "agency-to-agency" arrangement in place at the time. It was acknowledged, however, that "to a degree the concern went to the disruption operation. ${ }^{183}$ The operation of the Protocol remained suspended until the conclusion of a new MOU and Protocol on 13 June 2002. Despite the suspension of the Protocol, the AFP maintains that they continued to receive co-operation from the INP "on a case by case basis." 84

The Australian policy of disruption in Indonesia has been labelled "the untold story of people-smuggling." ${ }^{85}$ The Senate Select Committee pursued this story in some detail, in response to a submission raising questions about the sinking of a SIEV en route to Australia. This incident lead to the drowning of 353 asylum seekers - mostly women and children - and has become known as 'SIEV $\mathrm{X}$ ' ${ }^{86}$ In pursuing some of the issues raised by the SIEV $\mathrm{X}$ incident, the extent of disruption activities in Indonesia became apparent.

The primary objective for disruption activities is "to prevent the departure of the vessel in the first instance, to deter or dissuade passengers from actually boarding a vessel." ${ }^{\text {87 }}$ A distinction was drawn between dismantling and disruption efforts.

Dismantling is more focused on targeting the critical players, the facilitators, within the syndicate. So you are actually taking away a fulcrum for activity ... whereas disruption can extend far beyond the syndicate itself and ... target potential passengers on the vessel to disrupt their getting on board. ${ }^{88}$

Disruption activities included the interception and diversion of potential asylum seekers in Indonesia.

By disruption, we mean the use of the Indonesian national police to divert potential passengers to the International Organisation for Migration or the interception by the Indonesian national police of passengers prior to boarding vessels. What would happen ... is that potential passengers are gathered sometimes in a number of locations and at the last moment they are provided with details or transport to an embarkation point and they are placed on the vessels at the embarkation point. Often a disruption activity would be to prevent the passengers from getting to the point of embarkation or if we knew who the people smuggler was, to have the Indonesian national police arrest the organiser, or in other ways to disrupt the gathering of the people prior to the vessel departing. ${ }^{89}$ 
Other efforts that may fall within the general description of disruption activities include the distribution of information leaflets discouraging people in Indonesia from using a people smuggler to get to Australia, ${ }^{90}$ information campaigns directed at Indonesian fishermen who are usually recruited by people smugglers as "crew" forcement measures.

It was the role of the Special Intelligence Units of the INP, trained by the AFP, to conduct the disruption activities. On a number of occasions the AFP has emphasized the fact that Australia does not have the power to direct or command the INP; "we can seek their cooperation." 92 The INP invariably co-operates. However, the absence of a line of command raises serious accountability questions. As the AFP itself has stated, “[w]e don't know what they are up to but we know what we have requested of them." 93 The absence of accountability is particularly alarming in light of the fact that there appear to be no clear limits placed on disruption activities.

The Leader of the Opposition in the Senate, Senator Faulkner, has stated

It is not clear whether disruption extends to physical interference with vessels. It is not clear what, if any, consideration is given in the planning and implementation of disruption to questions of maritime safety, to the safety of lives at sea. ${ }^{94}$

These comments were made in response to allegations aired on a local television program that an informant in Indonesia had represented himself as a people smuggler. ${ }^{95}$ It was claimed that the informant - with the knowledge of either the AFP or the INP, or both - took money from asylum seekers in Indonesia on the basis that he would smuggle them to Australia. He claimed to be an Australian police officer who knew the movements of Australian Navy ships and so could get them to Australia. After taking money from the asylum seekers (around $\$ 1,000$ per person) he would then hand them over to the authorities in Indonesia. This informant also claims that Indonesian locals were paid on several occasions to sabotage people-smuggling boats with passengers on them.

Senator Ellison, Minister for Justice and Customs, has refuted any suggestion of an Australian official engaging in, or requesting the conducting of, this kind of activity.

Upstream disturbance has been a key strategy of the Howard government in dealing with people-smuggling ... Disruption and deterrence do not equate to sabotage. The Australian Federal Police has not been involved in sabotaging vessels but it has been involved in upstream disturbance - that is, disturbing and disrupting the activities of ruthless people-smugglers. ${ }^{96}$

Whilst the AFP maintains that it has not requested that the INP do anything illegal in relation to the disruption of people smuggling, it acknowledges that it has no way of knowing exactly what is being done in its name.

We are not privy to what network the INP necessarily used so I can't say whether they employed people to do this work on their behalf ... We knew when they arrested people or detained people, but we are not aware of how they did the other things they did. ${ }^{97}$

In relation to the overall policy of disruption of people smuggling in Indonesia, the majority ${ }^{98}$ of the Senate Select Committee concluded as follows

The Committee notes that it has not been able to gather more detailed information on the exact nature of the disruption measures employed in Indonesia. Further, it is concerned about the general lack of transparency surrounding elements of the strategy itself. In particular, the inability of the AFP to provide clear and precise information about the factors behind the Indonesian Government suspending the protocol governing the disruption effort compounds the sense of concern that a key diplomatic partner had cause to abrogate an element of the bilateral relationship. The Committee finds it perplexing that neither the AFP nor any other Australian agency took action to get to the bottom of this matter. The Committee considers that this matter warrants further investigation and reporting back to the Parliament. ${ }^{99}$

The Committee recommended that a full independent inquiry be conducted into

the disruption activity that occurred prior to the departure from Indonesia of refugee vessels ... with particular attention to the activity that Australia initiated or was instrumental in setting in motion through both its partners in the Indonesian government and its own network of informants. ${ }^{100}$

At the date of writing, no steps had been taken towards the implementation of this recommendation.

\section{Assessing the Impact of the Australian Policy}

Australia's comprehensive border protection measures seem to have been effective in that there have been no boat arrivals from Indonesia since 16 December 2001. Whilst the 
information campaigns, interception, and diversion activities in Indonesia have undoubtedly deterred asylum seekers from voyaging to Australia many of those people simply remain in Indonesia. The estimated number of people prevented from reaching Australia under the disruption program varies; however, in excess of 3,000 people appears to be a reasonable estimate. ${ }^{101}$

Whilst it is not possible to solely attribute the reduced flow of asylum seekers over the past twelve months to Australia's comprehensive border protection efforts, the introduction of the policy has coincided with a complete halt in the arrival of boats. As the Senate Select Committee noted:

The number of unauthorized boats attempting to reach Australia has declined dramatically, although the effect of the offshore processing arrangements and the new legislative regime in halting the flow of illegal boat arrivals is difficult to isolate from the influence of other factors, including disruption activities, regional anti-smuggling initiatives, the SIEV $\mathrm{X}$ disaster, and global developments such as increased border security in the aftermath of September 11, 2001. ${ }^{102}$

Through the introduction of a comprehensive border protection regime involving disruption, interdiction, redirection, and mandatory detention, Australia has managed to completely insulate itself from unauthorized boat arrivals of asylum seekers and refugees. For this reason, many other developed countries have shown particular interest in the Australian approach.

Most well known is the recent UK proposal for the introduction of regional protection areas ${ }^{103}$ - safe areas where UNHCR will be responsible for providing protection and humanitarian support to refugees, funded by the states redirecting asylum seekers to the area. Asylum seekers arriving in the EU would be identity screened at the external borders of the EU and removed to a regional protection area, based on their country of origin. Thus, it is proposed that there be an offshore (or outside EU) processing centre in Turkey for Iraqis, Somalia for Africans, and Morocco for Algerians and other Africans. It is made quite clear in the UK proposal that if UNHCR was not willing to participate in the scheme, the seemingly more compliant IOM would be approached. The UK proposal was strongly condemned by Human Rights Watch and other human rights organization. ${ }^{104}$ The proposal was not adopted by the European Council earlier this year. It is possible that the UK will look to partners outside the EU to implement the scheme, including Australia. ${ }^{105}$

The parallels between the UK proposal and Australia's Pacific Solution are quite striking, particularly the burden shift onto less developed countries and the UNHCR. According to Human Rights Watch, the UK acknowledges that "Australia's refugee policy is its source of inspiration." 106 One obvious point of distinction between the UK proposal and Australia's comprehensive border protection policy is that the UK policy would require the complete co-operation of all EU member states in order for it to be anywhere nearly as effective as Australia's has been. Australia's geography makes it unique in the developed world; people cannot simply walk or drive across Australia's borders. Slow-moving boats that are overflowing with people are readily detectable by a well-resourced and vigilant defence force. And they are certainly no match for naval warships.

\section{Conclusion}

Australia's border protection policy has generated much criticism, both domestically and internationally, especially from UN bodies and non-governmental organizations. The criticisms have, without exception, been ignored, largely because the Australian government does not believe it is in breach of any international obligations. Whilst this position may prove to be correct, the policy may be viewed as exploiting the greyer areas of refugee law, international human rights law, and the law of the sea. The policy certainly undermines Australia's long-standing reputation as a good international citizen and Australia's record as a human rights defender has been seriously tarnished. At best, the Australian policy pushes the limits of acceptable international practice. At worst, Australia has set a new "low water mark" for the treatment of asylum seekers and refugees.

The interception, return, and redirection of thousands of people - many of whom were subsequently recognized as refugees in need of international protection - and the shameless "burden shift" engaged in by Australia highlights the lengths to which a wealthy state can and will go to ensure the meeting of a domestic policy objective. That Australia's refugee "problem" is tiny by global standards is an even greater cause for alarm. It sends a dangerous message to all states that it is acceptable to "deflect" asylum seekers away from your territory when you feel that you have carried enough of the asylum burden. There are many states that would be far more justified in reaching this conclusion than Australia. If those states shut their borders to refugees and asylum seekers, the international refugee protection regime would be seriously jeopardized. Given the costs involved in hosting large numbers of refugees and asylum seekers, many host states will see the Australian policy as a tantalizing prospect. It is hoped that they resist the temptation to expand the Pacific Solution into a "European Solution" or an "Atlantic Solution." 
Appendix 1

Summary of SIEV Incidents 2001

\begin{tabular}{|c|c|c|c|c|c|}
\hline SIEV & $\begin{array}{c}\text { Date } \\
(2001)\end{array}$ & Where & $\begin{array}{c}\text { Australian } \\
\text { vessel }\end{array}$ & Action & Outcome \\
\hline Palapa & $27 / 8-3 / 9$ & $\begin{array}{c}\text { In vicinity of } \\
\text { (IVO) Christmas } \\
\text { Island }\end{array}$ & $\begin{array}{c}\text { Norwegian } \\
\text { freighter } M V \\
\text { Tampa }\end{array}$ & $\begin{array}{l}\text { Held in Australian } \\
\text { territorial waters by } \\
\text { SAS Transferred to } \\
\text { HMAS Manoora }\end{array}$ & $\begin{array}{l}\text { Transported to } \\
\text { Nauru (UNHCR } \\
\text { processing) }\end{array}$ \\
\hline 1 & $7-8 / 9$ & $\begin{array}{c}\text { IVO } \\
\text { Ashmore Reef }\end{array}$ & Warramunga & $\begin{array}{l}\text { Transferred to } \\
\text { HMAS Manoora }\end{array}$ & $\begin{array}{l}\text { Transported } \\
\text { to Nauru }\end{array}$ \\
\hline 2 & $10-22 / 9$ & $\begin{array}{c}\text { Aground } \\
\text { Ashmore Reef }\end{array}$ & $\begin{array}{l}\text { Newcastle, } \\
\text { Gawler }\end{array}$ & $\begin{array}{l}\text { Vessel foundered - held } \\
\text { off Ashmore on board } \\
\text { SEIV 1. Transferred to } \\
\text { HMAS Tobruk }\end{array}$ & \multirow[t]{2}{*}{$\begin{array}{c}\text { Transported } \\
\text { to Nauru }\end{array}$} \\
\hline 3 & $12-22 / 9$ & $\begin{array}{c}\text { IVO } \\
\text { Ashmore Reef }\end{array}$ & $\begin{array}{l}\text { Warramunga, } \\
\text { Geelong }\end{array}$ & $\begin{array}{c}\text { Held off Ashmore Reef. } \\
\text { Transferred to } \\
\text { Tobruk Reef }\end{array}$ & \\
\hline 4 & $6-10 / 10$ & $\begin{array}{c}\text { IVO } \\
\text { Christmas Island }\end{array}$ & Adelaide & $\begin{array}{l}\text { Taken under tow; SIEV } \\
\text { foundered, rescued }\end{array}$ & $\begin{array}{c}\text { Disembarked at } \\
\text { Christmas Island. } \\
\text { Taken to Papua New } \\
\text { Guinea (Manus) }\end{array}$ \\
\hline 5 & $12-19 / 10$ & $\begin{array}{c}\text { IVO } \\
\text { Ashmore Reef }\end{array}$ & $\begin{array}{l}\text { Warramunga } \\
\text { Whyalla } \\
\text { Townsville }\end{array}$ & $\begin{array}{l}\text { Escorted to AI lagoon } \\
\text { Removed to Indonesian } \\
\text { territorial waters }\end{array}$ & $\begin{array}{c}\text { Indonesia - Kupang, } \\
\text { West Timor }\end{array}$ \\
\hline 6 & $19-30 / 10$ & $\begin{array}{c}\text { IVO } \\
\text { Christmas Island }\end{array}$ & $\begin{array}{c}\text { Arunta } \\
\text { Warramunga }\end{array}$ & $\begin{array}{l}\text { Held in custody by AFP } \\
\text { \& AQIS Attempted } \\
\text { escort to Indonesian } \\
\text { territorial waters }\end{array}$ & $\begin{array}{l}\text { Vessel foundered, } \\
\text { returned to } \\
\text { Christmas Island. } \\
\text { Taken to Nauru }\end{array}$ \\
\hline 7 & $22-29 / 10$ & $\begin{array}{c}\text { IVO } \\
\text { Ashmore Reef }\end{array}$ & $\begin{array}{c}\text { Bunbury, } \\
\text { Arunta, Bendigo }\end{array}$ & $\begin{array}{c}\text { Held at Ashmore } \\
\text { Escorted to Indonesian } \\
\text { territorial waters }\end{array}$ & $\begin{array}{l}\text { Indonesia - Pepela, } \\
\text { Roti Island }\end{array}$ \\
\hline 8 & $29 / 10-10 / 11$ & $\begin{array}{c}\text { North-west } \\
\text { Bathurst Island }\end{array}$ & Wollongong & $\begin{array}{c}\text { Escorted to Ashmore and } \\
\text { held there Transferred to } \\
\text { HMAS Tobruk }\end{array}$ & \multirow{3}{*}{\begin{tabular}{|c} 
Transported to \& \\
disembarked at \\
Christmas Island \\
SIEV 9 passengers \\
then taken to Cocos \\
Is, most of SIEV 8 \& \\
10 to Nauru. Some \\
held at Christmas \\
Island until 26 Jan \\
02 then transferred \\
to Nauru
\end{tabular}} \\
\hline 9 & $31 / 10-10 / 11$ & $\begin{array}{c}\text { IVO } \\
\text { Ashmore Reef }\end{array}$ & $\begin{array}{l}\text { Arunta, } \\
\text { Bunbury, } \\
\text { Gladstone }\end{array}$ & $\begin{array}{c}\text { Towed to Ashmore Reef } \\
\text { and held there } \\
\text { Transferred to HMAS } \\
\text { Tobruk }\end{array}$ & \\
\hline 10 & $8 / 11$ & $\begin{array}{c}\text { IVO } \\
\text { Ashmore Reef }\end{array}$ & Wollongong & $\begin{array}{c}\text { Vessel caught fire and } \\
\text { sank. } 2 \text { deaths } \\
\text { Transferred to HMAS } \\
\text { Tobruk }\end{array}$ & \\
\hline 11 & $11-13 / 12$ & $\begin{array}{c}\text { IVO } \\
\text { Ashmore Reef }\end{array}$ & Leeuwin & $\begin{array}{l}\text { Escorted to Indonesian } \\
\text { territorial waters }\end{array}$ & Indonesia - Roti? \\
\hline 12 & $16-20 / 12$ & $\begin{array}{c}\text { IVO } \\
\text { Ashmore Reef }\end{array}$ & Leeuwin & $\begin{array}{l}\text { Escorted to Indonesian } \\
\text { terr }>\text { torial waters }\end{array}$ & Indonesia - Roti? \\
\hline $\mathrm{X}$ & $19-22 / 10$ & & $\begin{array}{l}\text { Departed } \\
\text { Sumatra } \\
\text { (Indonesia) }\end{array}$ & $\begin{array}{l}\text { Vessel sank en route to } \\
\text { CI, either in } \\
\text { international waters } \\
\text { south of Java or in IDTS } \\
\text { (Sunda Straits) }\end{array}$ & $\begin{array}{c}421 \text { passengers \& } \\
\text { crew including } 70 \\
\text { children. } 24 \\
\text { disembarked en } \\
\text { route. } 352 \text { drowned. } \\
44 \text { survivors (3 kids) }\end{array}$ \\
\hline
\end{tabular}




\section{Notes}

1. See, e.g., "Symposium-Australia's Tampa Incident: The Convergence of International and Domestic Refugee and Maritime Law in the Pacific Rim" (2003) 12 Pacific Rim Law and Policy Journal.

2. Convention Relating to the Status of Refugees, 28 July 1951, 189 U.N.T.S. 137 (entered into force 22 April 1954) [Refugee Convention].

3. For a discussion of the possible impact of Australia's border protection regime internationally, see Guy S. Goodwin-Gill, "Refugees and Responsibility in the Twenty-First Century: More Lessons Learned from the South Pacific" (2003) 12 Pacific Rim Law and Policy Journal 23 at 45-47.

4. Australian National Audit Office, Report No. 57: Management Framework for Preventing Unlawful Entry into Australian Territory (2001-02) at 9.

5. Until 11 November 2001 (the date of the most recent Australian federal election), DIMIA was known as the Department of Immigration and Multicultural Affairs (DIMA). This paper uses the name current at the relevant time, so both names are used.

6. Protocol Relating to the Status of Refugees, 31 January 1967, 606 U.N.T.S. 267 (entered into force 4 October 1967).

7. According to the UNHCR, the participating resettlement countries are Australia, Brazil, Burkina Faso, Canada, Chile, Denmark, Finland, Iceland, Ireland, The Netherlands, New Zealand, Norway, Sweden, and United States of America. See UNHCR Department of Protection, Easy Guide to Resettlement Programs (June 2002).

8. Don McMaster, Asylum Seekers: Australia's Response to Refugees (Melbourne; Melbourne University Press, 2002) at 60.

9. For a discussion of Australia's mandatory detention regime and its extension to desert and remote detention, see Kristie Dunn \& Jessica Howard, "Reaching behind Iron Bars: Challenges to the Detention of Asylum Seekers in Australia" (2003) 4 The Drawing Board 45.

10. Mary Crock \& Ben Saul, Future Seekers: Refugees and the Law in Australia (Sydney: Federation Press, 2002) at 33.

11. Prime Minister's Coastal Surveillance Task Force, Report (June 1999) para. 7, online: Department of Prime Minister and Cabinet Homepage <http://www.dpmc.gov.au> (date accessed: 6 November 2003).

12. Minister Philip Ruddock, Background Paper on Unauthorized Arrivals Strategy (2001), online: Minister for Immigration Homepage <http://www.minister.immi.gov.au> (date accessed: 6 November 2003).

13. Ibid.

14. These efforts have included agreement on joint co-operative activities in relation to border management with Papua New Guinea, document fraud training in Indonesia, Cambodia, and Vietnam and a Joint Ministerial Statement with Thailand on enhancing co-operation to combat irregular migration and people smuggling. See Background Paper on Unauthorized Arrivals Strategy, supra note.
15. Ibid

16. DIMIA, Fact Sheet No 74: Unauthorized Arrivals by Air and Sea (2002), online: DIMIA Homepage <http://www.dimia. gov.au> (date accessed: 6 November 2003).

17. DIMIA refers to these centres as "Immigration Reception and Processing Centres." The detention of asylum seekers in Australia has been the subject of much international criticism: see, e.g., Justice P. N. Bhagwati, Regional Advisor for Asia and the Pacific of the United Nations High Commissioner for Human Rights, Report on Mission to Australia: Human Rights and Immigration Detention in Australia (24 May to 2 June 2002); UN Commission on Human Rights, Report of the Working Group on Arbitrary Detention: Visit to Australia, UN Doc.E/CN.4/2003/8/Add.2 (24 October 2002).

18. The Afghan "rescuees" sent a letter to the Australian government while on board the MV Tampa saying, in part:

you know well about the long time war and its tragic human consequences and you know about the genocide and massacres going on in our country and thousands of us innocent men, women and children were put in public graveyards, and we hope that you understand that keeping view of above mentioned reasons we have no way but to run out of our dear homeland and to seek a peaceful asylum.

The letter was tendered in evidence during the hearing of proceedings brought on behalf of the "rescuees" See Victorian Council for Civil Liberties v. Minister for Immigration \& Multicultural Affairs, [2001] F.C.A. 1297 (11 September 2001, North J).

19. In an interview on 28 August 2001, Prime Minister Howard stated: "[W]e've taken the view, after taking a lot of advice, that it is not appropriate to allow that vessel to enter Australian waters, that it will not be given permission to land either at Christmas Island or somewhere else in Australia." Fran Kelly, Interview with John Howard, 7.30 Report, ABC TV (28 August 2001), online: ABC Homepage <http://www.abc.net.au> (date accessed: 6 November 2003).

20. Answers to Questions on Notice: "Timeline for Tampa Incident," Senate Select Committee on a Certain Maritime Incident, Parliament of Australia, Canberra, 5 July 2002 (Australian Maritime Safety Authority (AMSA) at 10 (copy on file with author).

21. Prime Minister John Howard, Doorstop Interview, Melbourne (31 August 2001), online: Prime Minister's Homepage $<$ http://www.pm.gov.au> (date accessed: 17 December 2002).

22. Victorian Council for Civil Liberties v, Minister for Immigration \& Multicultural Affairs, [2001] F.C.A. 1297 (North J).

23. Ruddock v. Vadarlis, [2001] F.C.A. 1329 (French and Beaumont JJ, Black CJ dissenting).

24. The First Administrative Arrangement between the Republic of Nauru and the Commonwealth of Australia "for joint cooperation in the humanitarian endeavours relating to asylum seekers" was signed on 10 September 2001 (copy on file with author). The two countries entered into a Memorandum of 
Understanding on 11 December 2001 (copy on file with author). Under the two agreements, Nauru agreed to accept a maximum of 1,200 asylum seekers at any one time on behalf of Australia on the understanding that all persons would be removed from Nauru once processed and that Australia would fully finance the costs of Nauru in hosting the asylum seekers. Australia further agreed to an assistance package for Nauru totalling over A $\$ 18$ million, including $\mathrm{A} \$ 4.5$ million for health related items, $\mathrm{A} \$ 3.45$ million in education assistance, $\mathrm{A} \$ 3.8$ million in fuel, $\mathrm{A} \$ 4.2$ million in power generation, $\mathrm{A} \$ 1$ million in rehabilitation support and $\mathrm{A} \$ 1.2$ million in miscellaneous items.

25. Prime Minister Helen Clark, Press Release, "New Zealand Offers to Admit Asylum Seekers" (1 September 2001), New Zealand Labour Party (copy on file with author).

26. On 12 September 2001, the Australian government formalized a verbal request made on 3 September 2001 that IOM "provide a range of services to the Australian Government in respect of unlawful asylum seekers transferred to offshore designated processing centres". An initial amount of $\mathrm{A} \$ 5$ million was advanced to IOM with all further costs to be reimbursed by the Australian government. Letter from Mr. W. Farmer, Secretary, DIMIA to Mr Denis Nihill, Chief of Mission - Regional Office, IOM, 12 September 2001 (copy on file with author). The letter was formally responded to by IOM on 17 September 2001 (copy on file with author).

27. Note verbale between UNHCR and the Government of Nauru, 20 September 2001 (copy on file with author).

28. In relation to IOM's costs, see Letter from DIMIA to IOM, supra note 26. In relation to UNHCR's cost, the Australian Government wrote to UNHCR on 5 October 2001, undertaking to "fully reimburse UNHCR for all staff and related costs incurred in assessing asylum claims in Nauru."

29. Evidence to Senate Select Committee on a Certain Maritime Incident, Parliament of Australia, Canberra, 16 April 2002, at 859 (Mr. William Farmer, Secretary, DIMIA).

30. On 11 October 2001, Australia and Papua New Guinea signed a Memorandum of Understanding which provided the "guiding principles for joint cooperation in relation to the operation of the immigration processing centre, including but not limited to, determining the identity and protection needs of persons and combating illegal migration and people smuggling" (copy on file with author). Under the MOU, Australia agreed to bear "all reasonable costs incurred" and to "support the Government of Papua New Guinea in its management of nationals from third countries who are illegally entering Papua New Guinea."

31. Senate Select Committee, Parliament of Australia, Report on a Certain Maritime Incident (2002), at 327 [11.60], online: Senate Committees Homepage <http://www.aph.gov.au/Senate/committee $>$ (date accessed: 6 November 2003).

32. These costs include both actual and budgeted costs, as follows: \$114.5 million budgeted (2001-02) for the establishment and operational costs of the offshore processing centres in Nauru and PNG; \$129.3 million budgeted (2002-03) for the costs of offshore reception and processing in offshore countries, on the basis of 4,500 new arrivals per annum; \$26.5 million in payments to Nauru pursuant to the MOU, in addition to the regular aid program; \$2.1 million for DFAT to cover the costs of a diplomatic presence on Nauru in support of the MOU for 2002-03; $\$ 660,000$ absorbed by DFAT in 2001-02 for cost of negotiations leading up to the Pacific Solution and the placement of a Temporary Consul on Nauru during 2001-02. An additional \$195 million (2001 to 2003) has been budgeted for the construction of a purpose-built Immigration Reception and Processing Centre on Christmas Island to house future arrivals.

33. Answers to Questions on Notice: Question 14, provided to the Senate Select Committee on a Certain Maritime Incident, Parliament of Australia, Canberra, 12 June 2002 (DIMIA) (copy on file with author). DIMIA noted that some cases cost in excess of $\$ 50,000$.

34. Report on a Certain Maritime Incident, supra note at 333 [11.91-2].

35. Chief of Defence Forces, Warning Order 007/01 dated 28 August 2001 (declassified), released to Senate Select Committee on a Certain Maritime Incident, Parliament of Australia, Canberra, 20 September 2002 (copy on file with author).

36. Ibid.

37. Evidence to Senate Select Committee on a Certain Maritime Incident, Parliament of Australia, Canberra, 5 April 2002, at 488 (Rear Admiral Smith).

38. Ibid. at 502 .

39. Evidence to Senate Select Committee on a Certain Maritime Incident, Parliament of Australia, Canberra, 22 May 2002, at 1629 (Rear Admiral Bonser, Director General Coastwatch, Australian Customs Service).

40. Evidence to Senate Select Committee on a Certain Maritime Incident, Parliament of Australia, Canberra, 4 April 2002, at 462 (Rear Admiral Smith).

41. See discussion of standard operating procedure, Evidence to Senate Select Committee on a Certain Maritime Incident, Parliament of Australia, Canberra, 5 April 2002, at 502 (Rear Admiral Smith).

42. Ibid.

43. Ibid. at 503 .

44. Ibid. at 504 .

45. Ibid.

46. The vessel in question was SIEV 4: Evidence to Senate Select Committee on a Certain Maritime Incident, Parliament of Australia, Canberra, 25 March 2002, at 159 (Commander Norman Banks, Royal Australian Navy).

47. Ibid. at 159 .

48. Evidence to Senate Select Committee on a Certain Maritime Incident, Parliament of Australia, Canberra, 25 March 2002, at 136 (Vice Admiral David Shackleton, Chief of Navy).

49. Evidence to Senate Select Committee on a Certain Maritime Incident, Parliament of Australia, Canberra, 4 April 2002, at 453 (Rear Admiral Geoffrey Smith, Maritime Commander). 
50. Evidence to Senate Select Committee on a Certain Maritime Incident, Parliament of Australia, Canberra, 5 April 2002, at 526 (Rear Admiral Geoffrey Smith, Maritime Commander).

51. Any rules of engagement require ministerial approval before they can be implemented: see, e.g., Evidence to Senate Select Committee on a Certain Maritime Incident, Parliament of Australia, Canberra, 16 April 2002, at 946 (Jane Halton, Former Chair People Smuggling Task Force).

52. Evidence to Senate Select Committee on a Certain Maritime Incident, Parliament of Australia, Canberra, 11 April 2002, at 660 (Rear Admiral Geoffrey Smith, Maritime Commander).

53. Ibid.

54. Evidence to Senate Select Committee on a Certain Maritime Incident, Parliament of Australia, Canberra, 25 March 2002, at 137 (Vice Admiral David Shackleton, Chief of Navy).

55. Ibid. at 136.

56. Evidence to Senate Select Committee on a Certain Maritime Incident, Parliament of Australia, Canberra, 5 April 2002, at 504 (Rear Admiral Geoffrey Smith, Maritime Commander).

57. Evidence to Senate Select Committee on a Certain Maritime Incident, Parliament of Australia, Canberra, 4 April 2002, at 462 (Rear Admiral Geoffrey Smith, Maritime Commander).

58. Evidence to Senate Select Committee on a Certain Maritime Incident, Parliament of Australia, Canberra, 5 April 2002, at 504 (Rear Admiral Smith).

59. Human Rights Watch, “By Invitation Only:” Australia's Asylum Policy (December 2002), at 43, online: Human Rights Watch Homepage <http://www.hrw.org> (date accessed: 6 November 2003).

60. Evidence to Senate Select Committee on a Certain Maritime Incident, Parliament of Australia, Canberra, 16 April 2002, at 917 (Jane Halton, Former Chair, People Smuggling Task Force).

61. Evidence to Senate Select Committee on a Certain Maritime Incident, Parliament of Australia, Canberra, 11 April 2002, at 662 (Rear Admiral Geoffrey Smith, Maritime Commander).

62. Evidence to Senate Select Committee on a Certain Maritime Incident, Parliament of Australia, Canberra, 25 March 2002, at 136 (Vice Admiral David Shackleton, Chief of Navy).

63. Evidence to Senate Select Committee on a Certain Maritime Incident, Parliament of Australia, Canberra, 1 May 2002, at 1452-3 (Dr. Geoff Raby, First Assistant Secretary, International Organisations and Legal Division, Department of Foreign Affairs and Trade).

64. Evidence to Senate Select Committee on a Certain Maritime Incident, Parliament of Australia, Canberra, 16 April 2002, at 823 (Edward Killesteyn, Deputy Secretary, DIMIA).

65. SIEV Event Summary, tabled as part of Evidence to Senate Select Committee on a Certain Maritime Incident, Parliament of Australia, Canberra, 5 April 2002 (Rear Admiral Smith) ("the Smith Report") (copy on file with author). This document can also be found as Appendix 3 to the Government Members Report, Report on a Certain Maritime Incident, supra note, enclosure 8 .
66. Article 33, Refugee Convention. The Australian government maintains that no one has been refouled from Indonesia, but appears not to have actively monitored any of the returnees.

67. Evidence to Senate Select Committee on a Certain Maritime Incident, Parliament of Australia, Canberra, 16 April 2002, at 823 (Edward Killesteyn, Deputy Secretary, DIMIA).

68. The information for this section is drawn from three main documents: Jana Mason, "Paying the Price: Australia, Indonesia Join Forces to Stop 'Irregular Migration' of Asylum Seekers” (2001) 22 Refugee Reports; DIMIA, People Smuggling Australia's experience and policy response (2002); and Background Paper on Unauthorized Arrivals Strategy, supra note .

69. Background Paper on Unauthorized Arrivals Strategy, supra note, Attachment B.

70. See Mason, supra note 68.

71. See Statute of the Office of the United Nations High Commissioner for Refugees, adopted by GA Res 428 , UN GAOR, $5^{\text {th }}$ sess, UN Doc. A/Res/428 (1950).

72. Mason, supra note 68, citing the Australian government's understanding of UNHCR's reluctance to take the lead role in the RCM.

73. Mason, supra note 68.

74. Evidence to Senate Select Committee on a Certain Maritime Incident, Parliament of Australia, Canberra, 16 April 2002, at 823 (Edward Killesteyn, Deputy Secretary, DIMIA).

75. Mason supra note 68.

76. Evidence to Senate Select Committee on a Certain Maritime Incident, Parliament of Australia, Canberra, 11 July 2002, at 1923 (Commissioner Michael Keelty, Australian Federal Police).

77. As at 31 March 2002, 481 people had been charged with people smuggling offences since the introduction of the crimes on 22 July 1999. In the financial year 2001-2002 to that date, 91 prosecutions had been finalized. See DIMIA Response to Questions on Notice, 13, Question 43, provided to the Senate Select Committee on a Certain Maritime Incident, Parliament of Australia, Canberra, 14 June 2002 (copy on file with author).

78. Evidence to Senate Select Committee (Keelty), supra note 76, at 1924.

79. Ministerial Direction (Supplementary), issued by Minister for Justice and Customs on 27 September 2000, pursuant to section 37(2) Australian Federal Police Act 1979 (Cth).

80. Commissioner Keelty, Statement of Clarification to the Senate Select Committee on a Certain Maritime Incident, 30 July 2002, at 1 (copy on file with author).

81. Ibid. at 2.

82. Ibid.

83. Evidence to Senate Select Committee (Keelty), supra note 76 at 1939.

84. Ibid.

85. Commonwealth, Parliamentary Debates, Senate, 23 September 2002, at 4690 (John Faulkner, Leader of the Opposition in the Senate). 
86. Many allegations have been raised about who is responsible for these deaths as the boat apparently sank in Indonesian territorial waters, but within the area in which Australia was conducting aerial surveillance at the time. Questions have also been raised about the extent of intelligence about SIEV X that was known to the Australian government and the PSTF at the time. None of the allegations about Australian knowledge or culpability have been substantiated. Information on SIEV X has been collated on the following website: <http://www. sievx.com>.

87. Evidence to Senate Select Committee on a Certain Maritime Incident, Parliament of Australia, Canberra, 11 July 2002, at 1934 (Federal Agent Brendon McDevitt, General Manager National, AFP).

88. Ibid. at 1933.

89. Evidence to Senate Select Committee (Keelty), supra note 76 at 1930.

90. See, for example, the "public awareness brochure" provided to the Senate Select Committee by DIMIA, Questions on Notice, (copy on file with author), the text of which provided (in Arabic and Indonesian):

\section{STOP! GOING TO AUSTRALIA ILLEGALLY?}

New Australian Laws ensure that those attempting to enter Australia illegally by boat will never live in Australia. Illegal boat arrivals will have no right to apply for asylum under the Australian system. The people smugglers are happy to take your money but they cannot deliver - they cannot get you to Australia. All recent arrivals at Ashmore Reef and Christmas Island have been transferred to places outside Australian jurisdiction including to Nauru and Papua New Guinea. Several boats have been returned to Indonesia (with all passengers) at the request of crews. Nobody has got access to Australia or its asylum system. If you get on a boat in Indonesia you will expose yourself and your family to great danger; lose your money; fail in your objective to get to Australia. The boats used by people smugglers are overcrowded and dangerous. Too many people have died trying to enter Australia by boat. Stop. Go back. Don't get further into the trap.

91. Evidence to Senate Select Committee on a Certain Maritime Incident, Parliament of Australia, Canberra, 11 July 2002, at 1999 (Ms Nelly Seigmund, Assistant Secretary, DIMIA).

92. Evidence to Senate Select Committee (Keelty), supra note 76 at 1938.

93. Ibid.

94. Commonwealth, Parliamentary Debates, Senate, 23 September 2002, at 4691 (John Faulkner, Leader of the Opposition in the Senate).

95. "The Federal Police and People Smugglers," Sunday, Nine Television, 1 September 2002, online: Sunday Homepage $<$ http://sunday.ninemsn.com.au $>$ (date accessed: 6 November 2003).

96. Commonwealth, Parliamentary Debates, Senate, 26 September 2002, at 4735 .
97. Evidence to Senate Select Committee (Keelty), supra note 76 at 1978.

98. The Committee report was not unanimous, with the government senators writing a dissenting report.

99. Report on a Certain Maritime Incident, supra note at 2 .

100. Ibid., Recommendation 1.

101. Australian Federal Police, Annual Report 2000-2001, (2001) at 33 .

102. Report on a Certain Maritime Incident, supra note at 334-35 para. 11.99 .

103. UK Government, A New Vision for Refugees (2003) (copy on file with author)

104. Human Rights Watch, An Unjust "Vision" for Europe's Refugees: Human Rights Watch Commentary on the UK's "New Vision" Proposal for the Establishment of Refugee Processing Centers Abroad (17 June 2003), online: Human Rights Watch Homepage <http://www.hrw.org > (date accessed: 6 November 2003).

105. The UK proposal states that this collaboration "may include other Western States such as Australia who are looking for new solutions to asylum and have to some extent piloted this approach ... Australia have been making noises that indicate that they may be willing partners": supra note 103 at 27.

106. Human Rights Watch, supra note at 2.

Jessica Howard, B.A., LL.B. (Hons) (Melb), Barrister \& Solicitor of the Supreme Court of Victoria, is a Ph.D. candidate at the Law School of the University of Melbourne, Australia. This paper forms part of the author's doctoral research into the legality under international law of Australia's interdiction of asylum seekers and refugees. The author would like to thank her supervisor, Professor Timothy McCormack, for his comments on earlier drafts of this paper. 